Ольга Довгий

ORCID: 0000-0002-3957-7857

Московский государственный университет Российский государственный гуманитарный университет

Москва, Россия

\title{
РИТОРИЧЕСКИЙ РЕЖИМ ПРОПОВЕДИ В САТИРАХ А.Д. КАНТЕМИРА
}

https://doi.org/10.34739/clit.2020.14.05

\section{THE SERMON'S RHETORICAL MODE IN A. CANTEMIR'S SATIRES}

The paper is a continuation of a series of publications by the author on the poetics of A. Cantemir's satires and is devoted to the interpretation of satires through the prism of speech modes - in particular, the mode of the sermon. The sermon is considered exclusively from an artistic point of view: as a speech of the consultative type (according to Aristotle), possessing a set of its own rhetorical techniques. A successive analysis of the functions of a «sermon» in five satires makes it possible to acknowledge the long-term benefits of the interpretation of satires from the perspectives of the sermon and confession modes, along with the possibility of studying the polyphonic tone of satires.

Keywords: A. Cantemir, satires, sermon, consultative speech, Aristotle, confession, «rhetorical speech nest-doll»

Сатиры А.Д. Кантемира - сложный организм. Чтобы понять, как он устроен, разглядеть конструкцию во всех деталях, нужно постоянно менять угол зрения. В своих публикациях о сатирах мы всякий раз стараемся использовать новый ракурс, особое внимание уделяя микроуровням текста ${ }^{1}$.

В настоящей статье мы подойдем к сатирам с принципиально новой стороны - речевых режимов; и конкретнее - проповеди. Проповедь рассматривается нами только с точки зрения художественной формы - как особым образом организованный тип

${ }^{1}$ О.Л. Кулагина, Сатиры А.Д. Кантемира: поэтика, контексты, интертексты, Автореферат докт. дисс..., Москва 2018, с. 45-48. 
речи, обладающий собственным набором риторических приемов. Если пользоваться классификацией типов речей по Аристотелю, то ближе всего она окажется к речи совещательной, направленной на то, чтобы «склонять или отклонять» 2 , цель которой - «польза, благо». Совещательная речь должна вызывать у слушателя надежду (на получение блага, если он будет следовать путем, предлагаемым проповедником) или страх (от наказания, если он с этого пути свернет).

Применительно к сатирам речь может идти о проповеди в широком смысле слова. Синонимами в этом случае окажутся слова «поучение», «нотация», «наставление», а английским эквивалентом «sermon». Этот тип речи строится по определенным законам. У него должны быть адресат, определенная тема, стержневое положение, заявленное в самом начале и проводимое сквозь череду доказательств (как подтверждающих, так и подвергающих его сомнению). Чем сильнее будет позиция противников - тем почетнее победа над ними. В конце точка зрения проповедника должна полностью восторжествовать, а аргументы противников должны быть посрамлены - и у адресата проповеди не должно возникнуть проблем с выбором.

Сатира телеологически близка проповеди: ее цель - склонять к добродетели и отклонять от пороков. Чем ярче описан порок - тем сильнее страх наказания. И проповедник, и сатирик имеют в своем техническом арсенале немало средств для создания впечатляющих картин как благодетельной, так и греховной жизни. И последующих воздаяний за ту и другую.

Мы рассмотрим пять сатир из восьми, в которых, на наш взгляд, наиболее ярко представлен режим «проповеди»3. Формальные признаки, по которым мы будем определять фрагменты сатир как «проповедь», - наличие адресата и употребление личных местоимений второго лица. Нетрудно предсказать, что основной оппозицией при описании этих «проповедей» будет оппозиция «серьезная/ироническая».

\section{Сатира первая - На хулящих учения. К уму своему}

Она вся, по сути, представляет собой проповедь, причем в целом - горькую и грустную. Но она может быть воспринята и как исповедь: большое число личных местоимений и глаголов первого лица

\footnotetext{
2 Аристотель, Риторика, пер. Н. Платоновой, [в:] Античныериторики, Москва, 1978, http://lib.ru/POEEAST/ARISTOTEL/ritoriki.txt, [дата доступа: 7.03.2020].

3 Сатиры Кантемира цит. по: А. Кантемир, Собрание стихотворений, Ленинград 1956, https://rvb.ru/18vek/kantemir/toc.htm, [дата доступа: 7.03.2020].
} 
единственного числа допускает такое прочтение. $\mathrm{y}$ «проповеди» первой сатиры тщательно продуманная драматургия.

Начинается «проповедь» с прямого обращения Автора к адресату («Уме недозрелый») и глаголов повелительного наклонения («покойся», «не понуждай к труду мои руки»). Первые 14 строк задают и тему проповеди (тяжелая жизнь ученых), и основную оппозицию в расстановке сил (ученый/те, кто над ним «смеется, гнушается»), и высокий эмоциональный тон: сильные сравнения (например, с мором) заставляют предположить богатый авторский потенциал (что ж будет дальше - если уже в первых строках он использует столь мощные средства). «Овцу не прибавит он к отцовскому стаду» - это явно не авторская речь. Это чужой голос, это реплика того «всякого», кто смеется над ученым.

Далее мы услышим еще несколько чужих голосов знаменитые монологи четырех хулителей наук. Это монологи в монологе, проповеди в проповеди. Они все разные. Но все откровенно иронические. Автор дает слово хулителям наук - чтобы они сами себя разоблачили, чтобы их глупость все сказала сама. И немалую роль играют авторские ремарки, описания внешнего вида ораторов: «ворчащий и вздыхающий» церковнослужитель Критон, «трожды рыгнувший» румяный Лука - какая им вера у читателя?

«Проповедь» первого - Критона с четками - по сути пародия на церковную проповедь. Пассаж про Критона тоже разнообразен в речевом отношении. Там есть и прямая речь:

«Расколы и ереси науки суть дети;

Больше врет, кому далось больше разумети;

Приходит в безбожие, кто над книгой тает...»,

и встроенная в нее поясняющая речь самого Автора «И просит свята душа, с горькими слезами/Смотреть, сколь семя наук вредно между нами». После этой вставки продолжение прямой речи Критона выглядит еще более смешным. А в самом конце монолога Критон приводит слова своего оппонента - фактически человека из лагеря Автора, критически настроенного к церковным порядкам: «Шепча, что тем, что мирской жизни уж отстали,/Поместья и вотчины весьма не пристали». Композиционно этими словами и заканчивается монолог Критона - безусловно, не случайно. Автор не дает читателю услышать ответ Критона оппоненту -выходит, Критон проиграл. Получается «речевая риторическая матрешка»: монолог Критона встроен в монолог Автора, а монолог обличаемого Критоном представителя ученой молодежи (хоть и очень краткий) - в монолог Критона. 
Следующий оратор - Силван - «другую вину наукам находит». Принцип разнообразия - один из главных в сатирах - проявляется и в их речевой организации. Силван строит свою речь на афористичных антитезах («Переняв чужой язык, свой хлеб потеряли»; «Землю в четверти делить без Евклида смыслим,/Сколько копеек в рубле без алгебры счислим»), на череде риторических вопросов, долженствующих доказать бессмысленность науки:

Прирастет ли мне с того день к жизни, иль в ящик

Хотя грош? могу ль чрез то узнать, что приказчик, Что дворецкий крадет в год? как прибавить воду

В мой пруд? как бочек число с винного заводу?

Его речь заключается ироническим авторским выводом, сводящим на нет все риторические подвиги Силвана:

Силван одно знание слично людям хвалит:

Что учит множить доход и расходы малит;

Трудиться в том, с чего вдруг карман не толстеет, Гражданству вредным весьма безумством звать смеет.

Третий оратор - румяный Лука - подходит к теме вреда наук с новой стороны. Его «проповедь» идет под лозунгом «Наука содружество людей разрушает». В своем пространном монологе он вводит оппозицию «друзья живые/друзья мертвые (книги)» и искусно склоняет слушателя в пользу выбора первых. Один из главных его аргументов - книги портят здоровье и сокращают жизнь:

В веселье, в пирах мы жизнь должны провождати:

И так она недолга - на что коротати,

Крушиться над книгою и повреждать очи?

Не лучше ли с кубком дни прогулять и ночи?

«Проповедь» Луки украшена ярким эпидейктическим пассажем-похвальным словом вину, составленным из формул Горация:

Вино - дар божественный, много в нем провору:

Дружит людей, подает повод к разговору,

Веселит, все тяжкие мысли отымает, Скудость знает облегчать, слабых ободряет, Жестоких мягчит сердца, угрюмость отводит, Любовник легче вином в цель свою доходит. 
Заключает Лука свою речь эффектным выпадом - фактически в сторону первого оратора: «Когда в пост чернец одну есть станет вязигу, - Тогда, оставя стакан, примуся за книгу». Так хулители наук уничтожают друг друга сами - и это тоже часть замысла Кантемира.

Четвертому оратору Медору не дается режима прямой речи: его «проповедь» вводится косвенно - при помощи глагола «тужит». Его аргументы против учености лежат в сфере телесной красоты и моды:

Медор тужит, что чресчур бумаги исходит На письмо, на печать книг, а ему приходит, Что не в чем уж завертеть завитые кудри.

После конспективного изложения «проповеди» Медора Автор вновь обращается к адресату своей проповеди с горьким советом, облеченным в форму исповеди:

Вот часть речей, что на всяк день звенят мне в уши;

Вот для чего я, уме, немее быть клуши

Советую. Когда нет пользы, ободряет

К трудам хвала, - без того сердце унывает.

Сколько ж больше вместо хвал да хулы терпети!

Трудней то, неж пьянице вина не имети,

Нежли не славить попу святую неделю,

Нежли купцу пиво пить не в три пуда хмелю.

Исповедь нужна как прием, как сильный личный аргумент в проповеди.

Отметим, что в этом пассаже Автор называет трех ораторов предыдущей части их подлинными именами - поп, купец, пьяница отчего их личные выгоды в произнесении проповедей делаются еще заметнее, а сами проповеди вызывают еще меньше доверия.

Далее Автор фиктивно дает слово адресату и вводит его аргументы:

\footnotetext{
Знаю, что можешь, уме, смело мне представить, Что трудно злонравному добродетель славить, Что щеголь, скупец, ханжа и таким подобны Науку должны хулить, - да речи их злобны Умным людям не устав, плюнуть на них можно; Изряден, хвален твой суд; так бы то быть должно, Да в наш век злобных слова умными владеют.
}

Точка зрения Ума - здравая и логичная, Автор согласен с ней. Но мир, изображенный в сатирах, - перевернутый; поэтому от похвалы наук в нем может быть только вред. В перевернутом мире 
главное - внешность, одежда. И Автор иронически советует Уму воспользоваться нехитрыми рецептами для легкого достижения высокого положения, используя параллельные конструкции:

Епископом хочешь быть - уберися в рясу (...)

Хочешь ли судьею стать - вздень перук с узлами (...)

Иронические рекомендации «правильного поведения» вводятся при помощи глаголов второго лица единственного числа:

Клобуком покрой главу, брюхо - бородою, Клюку пышно повели - везти пред тобою (...)

Брани того, кто просит с пустыми руками (...) Спи на стуле, когда дьяк выписку читает (...)

Тон Автора делается все более резким. Следует обличительный пассаж, в котором звучат афористичные формулы, дожившие до наших дней и слышен голос «всех», голос большинства:

Наука ободрана, в лоскутах обшита, Изо всех почти домов с ругательством сбита; Знаться с нею не хотят, бегут ея дружбы, Как, страдавши на море, корабельной службы. Все кричат: «Никакой плод не видим с науки, Ученых хоть голова полна - пусты руки».

Одна из целей авторской проповеди - показать масштабы беды: слова против наук звучат повсеместно. И Кантемир вводит голоса противников наук в разных частях своей проповеди - то прямой речью, то косвенной.

Мы услышим голос еще одного служителя церкви, для которого Автор находит убийственное определение напрочь уничтожающее его и без того смехотворные аргументы:

«Нет правды в людях, - кричит безмозглый церковник, Еще не епископ я, а знаю часовник, Псалтырь и послания бегло честь умею, В Златоусте не запнусь, хоть не разумею».

Претензии других недовольных своим положением вводятся уже знакомым по «проповеди» Медора способом - с помощью описывающего глагола: 
Писец тужит, что своим полком не владеет...

Воин ропщет, что за сукном не сидит красным...

Обидно себе быть, мнит в незнати старети... (курсив везде наш - О.Д.)

Практически каждый из описанных в первой сатире претендующих на высокое положение людей может быть определен авторским словом: «Хотя в прочем ни читать, ни писать не знает». Получается, что науки в современном Автору мире никак не помогают достичь желанной цели и совершенно бесполезны.

Заключает Автор свою проповедь грустным советом Уму:

Таковы слыша слова и примеры видя, Молчи, уме, не скучай, в незнатности сидя. Бесстрашно того житье, хоть и тяжко мнится,

Кто в тихом своем углу молчалив таится; Коли что дала ти знать мудрость всеблагая,

Весели тайно себя, в себе рассуждая

Пользу наук; не ищи, изъясняя тую, Вместо похвал, что ты ждешь, достать хулу злую.

Кольцевая композиция «проповеди» выдержана: в начале и в конце обращение «Уме», глаголы повелительного наклонения как в положительной, так и отрицательной форме. Посмотрим, какой сложится из них урок:

Покойся - не понуждай

Молчи - не скучай - весели тайно себя - не ищи

Иначе говоря, громко выступать в пользу наук - нажить беду, слышать хулу; путь умного - путь таящегося в тихом углу отшельника, тайно веселящего себя доступным ему одному знанием, полученным от всеблагой мудрости.

И надежда, и страх, и благо, и польза - все компоненты совещательной речи на месте.

Итак, первая сатира по своей речевой организации представляет собой искусно построенную проповедь, где позиции противников представлены ярко, разнообразно. Режим «риторической речевой матрешки» (вкрапление нескольких монологов в ткань общего монолога) оказывается очень продуктивным.

Сатирические «проповеди», безусловно, достигли цели.

Но достигнута ли общая цель проповеди? Отвратился ли Ум от наук, напугавшись страшных примеров? Отнюдь. Да и Автор в последних строках советует Уму веселить себя, изъясняя пользу наук. Но тайно. Так что вопросы о том, насколько удалась «проповедь» и насколько она была серьезной, остаются открытыми. И это лишний 
раз доказывает, что, по сути, первая сатира - исповедь, искусно замаскированная под сложно организованную проповедь.

\section{Сатира вторая - На зависть и гордость дворян злонравнъхх. Филарет и Евгений}

Она вся состоит из трех монологов: два раза слово берет Филарет и один раз Евгений.

Первый монолог Филарета представляет собой развернутый вопрос. «Что так смутен, дружок мой?» - обращается он к Евгению и сам выдвигает ряд заведомо ложных ответов, чтобы дать самому дать и верный ответ:

A, a! дознаюсь я сам, что тому причина:

Дамон на сих днях достал перемену чина,

Трифону лента дана, Туллий деревнями

Награжден - ты с пышными презрен именами.

Забыта крови твоей и слава и древность, Предков к общества добру многотрудна ревность

И преимуществ твоих толпа неоспорных, -

А зависти в тебе нет, как в попах соборных.

Весь ход речи Филарета, включая последнюю фразу, откровенно издевательскую, звучит как вызов. И Евгений вызов принимает - произносит горькую исповедь. В ней две главных мысли: похвала представителям древних родов, в особенности своему, известному уже во времена Ольги, и возмущение тем, что «кто недавно продавал в рядах мешок соли... Тот, на высоку ступень вспрыгнувши, блистает...».

Сам уж суди, как легко мне должно казаться, Столь славны предки имев, забытым остаться, Последним видеть себя, куды глаз ни вскину, -

жалуется Евгений другу.

А друг только этого и ждет. Вся остальная часть сатиры проповедь Филарета. Главная ее мысль - Евгений позорит свой род. Интересно - как он строит свою проповедь.

Начинает он с уверений в чистоте своих намерений:

Позволь уж мне мою мысль открыть и советы;

А ведай притом, что я лукавых приметы -

Лесть, похлебство - не люблю, но сердце согласно

С языком: что мыслит то, сей вымолвит ясно. 
Далее он переходит к мысли о том, что благородным человека делают не родовые грамоты, а собственные дела. Он обращает к Евгению череду однотипных риторических вопросов, призванных поселить в нем недовольство собой:

Презрев покой, снес ли ты сам труды военны?

Разогнал ли пред собой враги устрашенны?

К безопаству общества расширил ли власти

Нашей рубеж? Суд судя, забыл ли ты страсти?

Облегчил ли тяжкие подати народу?

Приложил ли к царскому что ни есть доходу?

Примером, словом твоим ободрены ль люди...

Разумеется, на все эти вопросы предполагается отрицательный ответ. Но Филарет идет к своей цели осторожно: он снова вспоминает предков Евгения и высказывает логичную мысль: «Если б ты им подражал, право б мог роптати,/Что за другими тебя и в пару не знати».

Следующий его риторический ход тоже вполне логичен: «Потрись на оселку, друг, покажи в чем славу/Крови собой - и твою жалобу быть праву».

«На оселку» испытывать друга будет, разумеется, сам Филарет - и пощады другу ждать не приходится.

Начинает Филарет свое испытание с фронтального синхронического сравнения Евгения с предками:

Пел петух, встала заря, лучи осветили

Солнца верхи гор - тогда войско выводили

На поле предки твои, а ты под парчою,

Углублен мягко в пуху телом и душою, Грозно соплешь, пока дня пробегут две доли...

На описание дня приятеля Филарет не жалеет иронических сравнений, активно пользуясь примерами из античной мифологии и древней истории. Результатом длительного пребывания Евгения «в краях чужестранных», «ущербившего пожитки», стало знание, «что фалды должны тверды быть, не жидки».

Один из важнейших упреков Евгению - он неграмотен: «Но те, что стенах твоей на пространной салы/Видишь надписи, прочесть труд тебе немалый».

Контраст - основной прием Филарета. От недостойной жизни Евгения он снова переходит к показу положительных примеров 
и рисует портреты образцовых деятелей в каждой сфере общественной жизни, не забывая стыдить Евгения:

Ты тех добродетелей, тех чуть имя знаний

Слыхал ли? Самых числу дивишься ты званий,

И в один все мозг вместить смертных столь мнишь трудно...

Ядовитые упреки высказываются напрямую, обращение «ты» звучит постоянно:

Как тебе вверить корабль? ты лодкой не правил... ...тебе еще реже

Снилась трубка и компас, чем строй и осада...

Все новые и новые аргументы для давно очевидного: Евгений не годен ни к какой службе. Но Филарет не унимается. Его тон делается все более резким, речь принимает откровенно обвинительный характер:

каменный душою,

Бъешь холопа до крови, что махнул рукою

Вместо правой - левою (зверям лишь прилична

Жадность крови; плоть в слуге твоей однолична).

Арсенал положительных примеров у Филарета обширен и разнообразен. От славных предков, сравнения с которыми не выдерживает Евгений, жесткий проповедник переходит к совсем обидным для Евгения людям - как раз к тем, о ком он с таким презрением говорил в своей исповеди. В пример приводится Клит, который проводит дни в передних знатных господ, «кланяясь и мухам». Такие сравнения должны быть невыносимы для дворянской гордости Евгения - и Филарет это знает. Оказывается, и Клит превосходит Евгения по всем статьям: у него есть масса важных достоинств для жизни при дворе, которых нет у Евгения: «Всего того я в тебе искать опасаюсь». Нельзя не признать, что Филарет пользуется риторически садистскими методами. На разные лады повторяет он мысль о никчемности Евгения - все более поднимая тон:

Ни одно не вижу я в тебе хвально свойство.

Исправь себя, и тогда жди, дружок, награду;

По тех пор забытым быть не считай в досаду. 
А завершает свою речь Филарет напоминанием о том, что и предки Евгения, которыми он так кичится, не всегда были наверху, что изначально все люди равны:

И твой род не все таков был, как потом стался, Но первый с предков твоих, что дворянин звался, Имел отца, славою гораздо поуже, Каков Трифон, Туллий был, или и похуже.

Адам дворян не родил, но одно с двух чадо Его сад копал, другой пас блеюще стадо; Ное в ковчеге с собой спас все себе равных Простых земледетелей, нравами лишь славных;

От них мы все сплошь пошли, один поранее Оставя дудку, соху, другой - попозднее.

На этом проповедь прекращается. Евгению, по всей видимости, морально совершенно уничтоженному, слова для оправдания не предоставляется.

Итак, вторая сатира искусно срежиссирована Филаретом: он сначала вызывает Евгения на исповедь, фактически провоцирует; а потом читает ему длинную эмоциональную проповедь, местами переходящую в обвинительную речь. Безусловно, Филарет во многом выражает авторскую позицию. Сам автор не может позволить себе такой эмоциональный накал, но может передать его персонажу. Если первая сатира граничит с горькой исповедью, то вторая с обвинительной речью. Во второй сатире Кантемиру не нужна «риторическая матрёшка»: ее полностью заменяет ораторское мастерство Филарета.

\section{Сатира четвертая - К музе своей. О опасности сатирических сочинений}

Речь, обращенная Автором к своей Музе, по всем признакам проповедь. Прямое обращение встречается несколько раз. В самом начале Автор прямо обозначает тему и цель своей проповеди отвратить музу от сочинения сатир: «Музо! не пора ли слог отменить твой грубый/И сатир уж не писать? Многим те не любы...»

Идет серия упреков Музе в излишней смелости - глаголы все время во втором лице единственного числа: «Смело хулишь, да к тому ж и говоришь внятно; /Досаждать злым вся жадна - то твое веселье...»

Суть проблемы в том, что смела Муза, а расплата за ее смелость - Автору: 
И ворчит уж не один, что, где нет мне дела, Там мешаюсь и кажу себя чресчур смела... ...А я вижу, что в чужом пиру мне похмелье...

Автор перечисляет обиженных Музой, готовых мстить ему. Среди преступлений Музы, обозначенных в доносах, есть очень страшные - например, «что нечистый в тебе дух бороду злословит».

«Музо, слог твой мне, творцу, ядовитый», - укоряет Автор Музу. А далее личное местоимение меняется со второго лица на первое: Автор как будто забывает, что обращался к Музе, и продолжает уже о себе, переводя проповедь в режим исповеди:

Знаю, что правду пишу и имен не значу, Смеюсь в стихах, а в сердце о злонравных плачу;

Да правда редко люба и часто некстати Кто же от тебя когда хотел правду знати?

А затем местоимения и вовсе начинают смешиваться и становится трудно понять, о ком говорит Автор - о себе или о своей Музе. Речь идет о сатире, ее сущности, целях и вреде сочинителю от нее. Потом, как бы опомнившись, Автор снова обрушивается на свою Музу. Его речь является ответом на фиктивные слова Музы:

Буде ты указывать смеешь Ювенала,

Персия, Горация, мысля, что как встала

Им от сатир не беда, но многая слава;

Что как того ж Боало причастник был права,

Так уже и мне, что следы их топчу, довлеет

То ж счастье, - позволь сказать, что ум твой шалеет.

Истая Зевсова дочь перо их водила -

Тебя чуть ли не с другим кем Память родила.

В них шутки вместе с умом цветут превосходным,

И слова гладко текут, как река природным

Током, и что в речах кто зрит себе досадно,

Не в досаду себе мнит, что сказано складно.

А в тебе что такого? без всякой украсы

Болтнешь, что не делают чернца одни рясы.

Автор пытается воспитать свою Музу, предлагая писать ложные похвалы:

Зачнем, музо, в похвалах перья притупляти,

Ну-тка станем Туллию приветство писати.

Туллий, знаешь ты, лукав, что если рассудно

Истолковать, то в нем ум выхвалить нетрудно. 
Оставя убо, что есть, сделаем такого, Каков бы он должен быть; тропа та не нова:

Всяк так пишет, кто хвалить у нас кого хочет, -

Тому, кого въявь поет, сам в сердце хохочет.

Однако далее Автор сам дискредитирует свои советы, определив такие похвальные стихи эпитетом «гадкие» («Буде ж несроден тебе род тех стихов гадких»), и предлагает Музе новый путь написание любовных стихов. Глаголы повелительного наклонения следуют один за другим:

Запой в Амариллиных объятиях сладких Счастливого Титира иль Ирис, бесщадну К бедну Филену.

Вскинь глаза на прошлу жизнь мою и подробно

Исследуй: счастье ко мне ласково и злобно Бывало, больше в своей злобе постоянно.

Почерпнув довольну тут печаль, нечаянно Новым уж родом стихов наполним тетрати...

«Наполним» - это новая глагольная форма, свидетельствующая о желании Автора достичь согласия с Музой. Писать о чем угодно - только не сатиру - уговаривает Музу Автор:

Есть о чем писать, - была б лишь к тому охота,

Было б кому работать - без конца работа!

А лучше век не писать, чем писать сатиру,

Что приводит в ненависть меня всему миру!

Автор, уговаривая Музу, дал подробный реестр различных видов стихов, предсказал будущую моду на унылую элегию, однако своей главной цели не достиг. Попытки уговорить Музу писать что-то, кроме сатиры, окончились неудачей:

Но вижу, музо, ворчишь, жмешься и краснеешь,

Являя, что ты хвалить достойных не смеешь,

А в ложных хвалах нурить ты не хочешь время.

Достойных, право, хвалить - не наших плеч бремя...

Автор согласен с Музой - снова появляется местоимение первого лица множественного числа («не наших плеч бремя»). И новые аргументы против писания ложных похвал - уже от первого лица единственного числа: 
К тому ж человечья жизнь редко однолична:

Пока пишется кому похвала прилична, Добродетель его вся вдруг уж улетает, И смраден в пятнах глазам нашим представляет

Себя, кто мало пред тем бел, как снег, казался.

Куды тогда труд стихов моих уж девался?

Пойду ль уже чучело искать я другое, Кому б тые прилепить? иль, хотя иное

В нем вижу сердце, ему ж оставя, образу

Себе в людях навлеку, кои больше глазу

Верить станут своему, нежли моей бредни, Не меряя доброту по толпе в передни.

Далее Автор признается, что его попытки «сломить нрав» своей Музы ни к чему хорошему не приводят. Он рисует впечатляющую картину смены своего творческого направления:

А я знаю, что когда хвалы принимаюсь Писать, когда, музо, твой нрав сломить стараюсь, Сколько ногти ни грызу и тру лоб вспотелый, С трудом стишка два сплету, да и те неспелы, Жестки, досадны ушам и на те походят, Что по целой азбуке святых житье водят. Дух твой ленив, и в зубах вязнет твое слово, Не забавно, не красно, не сильно, не ново; А как в нравах вредно что усмотрю, умняе Сама ставши, - под пером стих течет скоряе. Чувствую сам, что тогда в своей воде плавлю И что чтецов я своих зевать не заставлю: Проворен, весел спешу, как вождь на победу, Или как поп с похорон к жирному обеду.

Тон Автора делается все более уверенным и мажорным. Число местоимений первого лица с единственного сменяется на множественное:

Одним словом, сатиру лишь писать нам сродно:

В другом неудачливы; с нравом же несходно Моим, не писав, прожить в лености с тобою.

Ин, каков бы ни был рок, смелою рукою Злой нрав станем мы пятнать везде неостудно.

Трудно не увидеть здесь перекличку с первой сатирой. Ключевое слово для сравнения - деепричастие «не писав». В первой, «не писав», можно было «славу достать», а в 4-ой - «не писав», нельзя прожить. Эта «проповедь», как и в случае с первой сатирой, формально 
должна быть признана неудачной: Автор, вместо того, чтобы отвратить Музу от писания сатир, принимает ее сторону и поет песнь хвалебную сатирам, обещая писать их и впредь. Откуда такая смелость? Только ли оттого, что Автор надеется на защиту императрицы? Или стратегия «неудачной проповеди» - это риторический ход? В заглавие вынесена «опасность сатирических сочинений». А сатирик не испугался опасности. Так совещательная по форме речь превращается в эпидейктическую по смыслу. В хвалу самому жанру сатиры.

\section{Сатира пятая - На человеческие злонравия вообще. Сатир и Периерг}

Начинается она с ворчливого монолога Сатира, недовольного людьми. Появляется Периерг, удивляется странному виду Сатира (он «в штанах и кафтане») и решает вызвать его на исповедь, о чем прямо сообщает читателю. В качестве располагающих к доверию приемов он использует череду лобовых вопросов («кто ты?» «откуду путь держишь?, «куда идешь») и уверения в чистоте своих намерений и «неложной готовности услужить». Сатир резким антанакласисом отвергает риторические приступы Сатира («прочь от меня, неложно мне к службе готовый») и произносит очень недружелюбные слова в адрес рода человеческого. Периерг пытается убедить Сатира, что люди не все одинаковы. Сатир соглашается за время переодевания удовлетворить любопытство собеседника (благо и имя у того говорящее). Риторические приемы Периерга напоминают приемы Филарета, но Периерг пытается направлять течение речи Сатира хотя и безуспешно. Начавшись с рассказа о жизни в городе, речь перерастает в гневную проповедь, обращенную ко всему роду человеческому. Сатир говорит как заправский ритор, используя эффектные антитезы, перечисления, риторические вопросы, различные метафорические коды. Рассказ о персонажах с именами собственными (Макар, Хирон и т.д.) чередуется с упоминанием безымянных, но столь же смешных на взгляд обитателя леса, персонажей, определенных их профессией или социальным положением (купец, пахарь, чернец, солдат и т.д.). Активно пользуется Сатир и режимом «риторической речевой матрёшки», вставляя свою речь «исповеди» высмеиваемых персонажей (например, Старика сановитого). Все эти приемы делают «проповедь» Сатира яркой, образной, конкретной, доходящей до сердца слушателя. Кантемир искусно пользуется приемом остранения: из уст лесного жителя обвинения людям в непостоянстве и отсутствии воли звучат особенно впечатляюще: 
Бессчетных страстей рабы! от детства до гроба

Гордость, зависть мучит вас, лакомство и злоба,

Самолюбье и вещей тщетных гнусна воля;

К свободе охотники - впилась в вас неволя.

Так, как легкое перо, коим ветр играет,

Час мал пробыть на одном мысль ваша не знает.

То богатство ищете - то деньги мешают,

То грустно быть одному - то люди скучают;

Не знаете сами, что хотеть; теперь тое

Хвалите, потом - сие, с одно на другое

Пременяя мысль свою, и, что паче дивно,

Вдруг одно желание другому противно.

Вся «проповедь» обращена к людям вообще (не случайно и название «На человеческие злонравия вообще») - о чем говорит употребление личного местоимения второго лица множественного числа. Сатир не объединяет себя с людьми, смотрит на них со стороны - поэтому и не щадит их. В конце «проповеди» Сатир меняет адресата - и обращается уже непосредственно вызвавшему его на эту гневную речь Периергу, дает ему совет.

\section{Речь мою про себя крой, буде в ней какую \\ Пользу чаешь; не ищи употреблять тую \\ К исправлению людей: мала к тому сила \\ Наша с тобой - исправит горбатых могила.}

Этот грустный финал, безусловно, перекликается с финалом первой сатиры: в нем содержится совет обладающему знанием держать это знание про себя, не делиться с людьми.

В принципах речевой организации пятая сатира перекликается и со второй. Во второй Филарет, желающий произнести обличающую проповедь, сначала провоцирует ее адресата на исповедь, а затем громит его, не давая вставить ни слова. В пятой Периерг вызывает Сатира на исповедь, чтобы посмеяться. Но срабатывает эффект обманутого ожидания. Вместо исповеди смешного лесного человека Периерг слышит резкую проповедь в адрес всех людей и себе в первую очередь.

\section{Шестая сатира О истинном блажсентве}

Она тоже может быть рассмотрена как «проповедь». Начинается она с сентенции, взятой из Горация: «Тот в сей жизни лишь блажен, кто малым доволен...», продолжается как авторская «исповедь», о чем свидетельствует местоимение первого лица единственного числа («Желания все мои крайни составляет»). Дальше 
появляется некий виртуальный адресат («хоть ты помнишь...», «тебе чин маленький доставят»), к которому и обращен весь рассказ о трудностях, ожидающих ищущего чинов. В 125 строке появляется местоимение «мы» - как обобщенное обращение ко всем людям. Автор, в отличие от Сатира в 5-й сатире, не отделяет себя от остальных людей, признает за собой все человеческие недостатки. Но в течение речи снова появляется личное местоимение второго лица единственного числа:

Можно славу получить, хоть бы за собою Полк людей ты не водил, хоть бы пред тобою Народ шапки не сымал, хоть бы ты таскался Пешком, и один слуга тебя лишь боялся.

И заканчивается сатира тоже обращением к виртуальному слушателю:

\author{
...живи тих, ища, что честно, \\ Что и тебе и другим пользует нелестно \\ К нравов исправлению; слава твоя вечно \\ Между добрыми людьми жить будет, конечно. \\ Да хоть бы неведом дни скончал и по смерти \\ Свету остался забыт, силен ты был стерти \\ Зуб зависти, ни трудов твоих мзда пропала: \\ Добрым быть - собою мзда есть уже немала.
}

Тема «тайного тихого житья», уже знакомая по предыдущим сатирам», обогащается здесь мотивом житья добродетельного. К тайному знанию наук (первая сатира) и человеческих пороков (пятая сатира) добавляется тайная доброта нрава. Портрет «отшельника» делается все более идеальным, а «тайное житье» все более привлекательным, т.к. доступно только избранным. Сентенция «Добрым быть - собою мзда есть уже немала» во многом синонимична совету «веселить тайно себя, в себе изъясняя пользу наук», что «дала знать Мудрость всеблагая». Не исключено, что обращение «ты» является риторическим замещением «я». В первой сатире в этой роли выступало обращение к Уму, в четвёртой - к Музе. Но формально шестую сатиру вполне можно отнести к режиму «проповеди»: обращение, смысловое наполнение, цель позволяют это сделать.

Итак, мы бросили очень беглый взгляд на функции «проповеди» в сатирах. Оппозиция «проповедь серьезная/проповедь ироническая» проходит через весь текст сатир и позволяет ярче увидеть два основных модуса: обличительный и эпидейктический. Если наличие обличительного модуса в сатирах не вызывает 
удивления, то эпидейксис заслуживает отдельного разговора. Наличие этих двух модусов напрямую связано с двойной направленностью любой совещательной речи (и проповеди в том числе): «склонять и отклонять». Разнообразие средств, используемых Кантемиром для «отклонения», осмеяния, можно изучать бесконечно. Но не менее разнообразен он и в эпидейксисе. Главное средство его здесь - «обман читателя»: уверения, что «хвалить не наших плеч бремя».

А на самом-то деле главным в сатирах является совсем не обличение пороков - как ни парадоксально это звучит. Главное похвала: похвала блаженству «тихого угла», где можно «тайно веселить себя» беседами с «мертвыми греки и латины»; похвала доброте нравов, похвала сатире, похвала Уму. Похвала всему, что хулит большинство; похвала по антитезе. Не случайно «проповеди» первой и четвертой сатир «не достигли цели»: Ум не отвратился от наук, а Автор от писания сатир. В перевернутом мире и похвала подается в перевернутой форме. Особого внимания заслуживает прием «речевой риторической матрешки», активно используемый Кантемиром. Он создает богатые возможности для придания сатирам полифонического звучания.

Взгляд на сатиры сквозь призму речевых стратегий открывает принципиально новое поле для исследования их поэтики. А в целом открытие новых перспектив исследования - новое свидетельство неисчерпаемости поэтического мира сатир.

\section{Литература}

Аристотель, Риторика, пер. Н. Платоновой, [в:] Античные риторики, Москва 1978, http://lib.ru/POEEAST/ARISTOTEL/ritoriki.txt.

Кантемир А., Собрание стихотворений. Ленинград 1956, https://rvb.ru/ 18vek/kantemir/toc.htm.

Кулагина О.Л., Сатиры А.Д. Кантемира: поэтика, контексты, интертексты, Автореферат докт. дисс..., Москва 2018.

\section{References}

Aristotel', Ritorika, per. N.Platonovoj, [v:] Antičnye ritoriki, Moskva 1978, http://lib.ru/POEEAST/ARISTOTEL/ritoriki.txt.

Kantemir A., Sobranie stihotvorenij, Leningrad 1956, https://rvb.ru/18vek/ kantemir/toc.htm.

Kulagina O.L., Satiry A.D. Kantemira: poètika, konteksty, interteksty, Avtoreferat dokt. diss..., Moskva 2018. 